\title{
Assessment of bone marrow involvement in patients with lymphoma: report on a consensus meeting of the Korean Society of Hematology Lymphoma Working Party
}

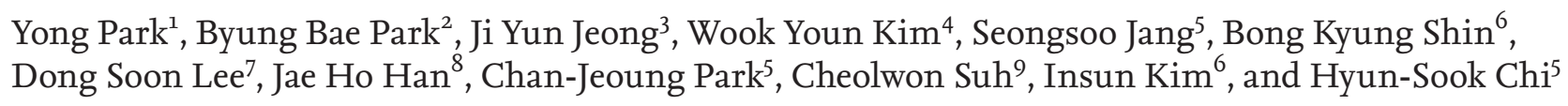

\begin{abstract}
${ }^{1}$ Department of Internal Medicine, Korea University School of Medicine, Seoul; ${ }^{2}$ Department of Internal Medicine, Hanyang University College of Medicine, Seoul; ${ }^{3}$ Department of Pathology, Kyungpook National University School of Medicine, Daegu; ${ }^{4}$ Department of Pathology, Konkuk University Medical Center, Seoul; ${ }^{5}$ Department of Laboratory Medicine, University of Ulsan College of Medicine, Seoul; ${ }^{6}$ Department of Pathology, Korea University School of Medicine, Seoul; ${ }^{7}$ Department of Laboratory Medicine, Seoul National University College of Medicine, Seoul; ${ }^{8}$ Department of Pathology, Ajou University School of Medicine, Suwon; ${ }^{9}$ Department of Oncology, Asan Medical Center, University of Ulsan College of Medicine, Seoul, Korea
\end{abstract}

Received: January 6, 2015 Accepted: October 14, 2016
In September 2011, the Korean Society of Hematology Lymphoma Working Party held a nationwide conference to establish a consensus for assessing bone marrow (BM) involvement in patients with lymphoma. At this conference, many clinicians, hematopathologists, and diagnostic hematologists discussed various topics for a uniform consensus in the evaluation process to determine whether the BM is involved. Now that the discussion has matured sufficiently to be published, we herein describe the consensus reached and limitations in current methods for assessing BM involvement in patients with lymphoma.

Keywords: Lymphoid malignancies; Bone marrow involvement; Consensus report; Korean Society of Hematology Lymphoma Working Party

\section{Correspondence to Cheolwon Suh, M.D.}

Department of Oncology, Asan Medical Center, University of Ulsan College of Medicine,

88 Olympic-ro 43-gil, Songpa-gu, Seoul 05505, Korea

Tel: +82-2-3010-3209

Fax: $+82-2-3010-6961$

E-mail: csuh@amc.seoul.kr

\section{INTRODUCTION}

The evaluation of bone marrow (BM) status is a key process in the initial workup of patients diagnosed with lymphoma. Despite its importance, the complexity of the BM evaluation process has sometimes caused institutional heterogeneity and may be an obstacle in multi-center clinical trials involving patients with lymphoma.
In September 2011, the Korean Society of Hematology Lymphoma Working Party held a nationwide conference to establish a consensus for assessing BM involvement in patients with lymphoma. At this conference, many clinicians, hematopathologists, and diagnostic hematologists discussed various topics for a uniform consensus in the evaluation process to determine whether the $\mathrm{BM}$ is involved. It is now considered to have become sufficiently mature to be published. Hence, in this report, we 
describe the consensus reached and the limitations in current methods for assessing BM involvement in patients with lymphoma.

\section{IMPORTANCE OF A BONE MARROW EXAMINATION IN LYMPHOMA}

The BM is the most common site of extranodal involvement in lymphoid malignancies and the frequency of $\mathrm{BM}$ involvement varies according to the lymphoma subtype (Table 1). Compared to aggressive lymphoma, relatively high frequencies have been reported in indolent lymphomas, such as mantle cell lymphoma (MCL), follicular lymphoma (FL), and marginal-zone lymphoma [1]. Because BM involvement of lymphoma is definite evidence of disseminated disease $[2,3]$, the assessment of BM status in patients with lymphoma provides important information for decisions regarding treatment. In particular, in the subtypes of lymphoma in which local treatment modalities, such as radiotherapy and concurrent chemoradiation, have a role in definitive therapy, knowledge about the presence or absence of BM involvement is vital. Hodgkin lymphoma, FL, mucosa-associated lymphoid tissue (MALT) lymphoma, and extranodal NK/T cell lymphoma, nasal type, are examples $[4,5]$.

Currently, noninvasive clinical staging by computed tomography (CT), magnetic resonance imaging (MRI), or positron emission tomography (PET)-CT cannot fully

Table 1. Incidence of bone marrow involvement in non-Hodgkin lymphoma

\begin{tabular}{lc}
\hline NHL subtype & \% BM involvement \\
\hline Small lymphocytic lymphoma & $>75$ \\
Mantle cell lymphoma & $55-90$ \\
Follicular lymphoma & $50-60$ \\
Splenic marginal zone lymphoma & $70-100$ \\
Other marginal zone lymphoma & $30-40$ \\
Lymphoplasmacytic lymphoma & $>80$ \\
Diffuse large B cell lymphoma & $20-30$ \\
T cell rich large B cell lymphoma & $25-60$ \\
Burkitt lymphoma & $>40$ \\
Hepatosplenic T cell lymphoma & $>95$ \\
\hline
\end{tabular}

NHL, non-Hodgkin lymphoma; BM, bone marrow. assess BM involvement, which is possible only by pathological staging (aspiration and trephine biopsy). Thus, although clinical stage can suggest localized diseases (stage I or II), it is not uncommon for the final stage to change to stage IV due to positive BM involvement. For example, recent studies that have analyzed patients with MALT lymphoma have demonstrated that a considerable proportion of patients (10\% to $44 \%$ ) shows BM involvement despite single MALT organ disease [6-8].

Determining BM status is important for the prognosis of patients. The International Prognostic Index (IPI) consists of five clinical variables: age, serum levels of lactate dehydrogenase (LDH), performance status (PS), stage, and extranodal involvement. Of these, BM status can influence both stage and extranodal involvement. If a patient of clinical stage IE (e.g., gastric lymphoma) has only one positive variable among age, serum LDH, and PS, the prognosis may depend mainly on the BM status. With no BM involvement, the IPI score would be 1 and this patient would be in the low-risk group. In contrast, positive BM involvement makes the IPI score 3 , placing the patient in the intermediate-high risk group. According to the IPI system, the low-risk group shows a response rate of 87\%, 70\% 5-year relapse-free survival, and $73 \% 5$-year overall survival. However, the intermediate-high risk group shows a response rate of $55 \%, 49 \%$ 5-year relapse-free survival, and 43\% 5-year overall survival [9]. A recent trial suggested that frontline autologous stem cell transplantation may provide clinical benefits to high-risk patients with aggressive non-Hodgkin lymphoma (NHL) compared to low-risk patients $[10,11]$.

\section{ROLE OF MORPHOLOGY AND IMMUNOHISTOCHEMICAL ANALYSES}

The pattern of infiltration is a key morphological feature to consider when generating a logical list of differential diagnostic considerations. These infiltration patterns, although not absolutely specific, may provide diagnostic clues both for the discrimination of benign and malignant infiltrates and for NHL subtyping. However, patterns can change during the course of the disease, and mixed patterns frequently occur. Five major patterns of BM infiltration can be discerned (Table 2) [12].

Nevertheless, the morphological features of lympho- 
Table 2. Patterns of lymphomatous bone marrow

\begin{tabular}{|c|c|c|}
\hline Pattern & Definition & Predominant subtypes \\
\hline Focal, random & Discrete lesion evident on low magnification & SLL, MCL, SMZL \\
\hline Focal, paratrabecular & $\begin{array}{l}\text { Discrete lesion by molding of lymphoma infiltrate } \\
\text { against bony trabeculae }\end{array}$ & FL, MCL \\
\hline Intravacular, intrasinusoidal & Neoplastic cells localized to sinuses and small vessels & SMZBCL, HSTL \\
\hline $\begin{array}{l}\text { Interstitial, diffuse, } \\
\text { and variably patchy }\end{array}$ & Neoplastic cells dispersed throughout medullary space & BL, LL, ALCL, ENKTL \\
\hline Diffuse solid & $\begin{array}{l}\text { Discrete areas of complete effacement of BM between } \\
2 \text { bony trabeculae }\end{array}$ & $\begin{array}{l}\text { BL, PTCL-NOS, LL, SLL, } \\
\text { LPL, MCL, FL, SMZL }\end{array}$ \\
\hline
\end{tabular}

SLL, small lymphocytic lymphoma; MCL, mantle cell lymphoma; SMZL, splenic marginal zone lymphoma; FL, follicular lymphoma; HSTL, hepatosplenic T cell lymphoma; BL, Burkitt lymphoma; LL, lymphoblastic lymphoma; ALCL, anaplastic large cell lymphoma; ENKTL, extranodal NK/T cell lymphoma; PTCL-NOS, peripheral T cell lymphoma, not otherwise specified; LPL, lymphoplasmacytic lymphoma.

ma in BM involvement vary widely and frequently differ from these typical patterns. Particularly in cases with individual infiltration of lymphoma cells, it can be difficult to recognize the involvement of lymphoma in BM. Moreover, the histological features of BM involvement are sometimes discordant with those of extramedullary lesions. Thus, in addition to a morphological assessment, immunohistochemical studies are required for a complete diagnostic approach. Features of the morphological, immunohistochemical, and diagnostic clues are summarized in Tables 3 (B-NHL) and 4 (T-NHL) [12].

\section{Small B cell NHLs}

Small B cell NHLs include chronic lymphocytic leukemia/small lymphocytic lymphoma (CLL/SLL), lymphoplasmacytic lymphoma (LPL), FL, MCL, and marginal-zone lymphoma. They frequently involve the BM and make up a large percentage of cases of BM infiltrates in patients with lymphomas.

CLL/SLL is usually of B cell origin and involves the $\mathrm{BM}$ and peripheral blood. The involved BM is usually hypercellular, with interstitial, nodular, and mixed or diffuse infiltration of small neoplastic lymphocytes with clumped chromatin and scanty cytoplasm. Proliferation centers with larger cells are less common than in lymph nodes. Immunohistochemically, the tumor cells are positive for $\mathrm{CD}_{19}$, $\mathrm{CD}_{20}$, CD79a, $\mathrm{CD}_{23}, \mathrm{CD}_{5}$, and $\mathrm{CD}_{43}$ but negative for cyclin D1 [13-15].

MCL involves the BM in $55 \%$ to $90 \%$ of cases and can show various patterns, including predominantly para- trabecular infiltrates with a uniform population of small to medium-sized lymphocytes having cleaved or angular nuclei, dispersed chromatin, inconspicuous nucleoli, and scant cytoplasm [16]. The tumor cells usually express surface immunoglobulin M (IgM), CD19, CD2O, $\mathrm{CD}_{22}, \mathrm{CD}_{79 a}, \mathrm{CD}_{5}, \mathrm{CD}_{43}$, and characteristically, cyclin D1. Demonstration of the characteristic $\mathrm{CD}_{5}+\mathrm{CD}_{23}{ }^{-} \mathrm{im}-$ munophenotype and of cyclin Di expression, complemented by $\mathrm{CD}_{20} \mathrm{o}$ staining, is very sensitive for the detection of residual disease. Blastoid and pleomorphic variants of MCL have to be distinguished from lymphoblastic lymphoma (LL)/acute leukemia and large-cell lymphoma [12].

Low-grade FLs show BM involvement in 50\% to $60 \%$ of cases. In the BM, FL cells are characteristically localized in the paratrabecular region, but may infiltrate interstitially with significant fibrosis and be virtually invisible in an ordinary morphological examination. The follicular growth pattern, which is typical in lymph nodes, is only seen rarely. Immunohistochemically, the lymphoma cells are positive for surface Ig, CD19, CD2O, $\mathrm{CD}_{22}, \mathrm{CD}_{79} \mathrm{a}$, bcl2, bc16, and $\mathrm{CD} 10$, and negative for $\mathrm{CD}_{5}$ and CD23 [17].

Nodal and extranodal marginal zone lymphomas (MZLs) infiltrate the BM less frequently than in other small B cell NHLs, possibly with a higher frequency for nodal MZL. They usually show intertrabecular, nodular infiltrates, which may contain reactive germinal centers [16]. Central nodules and patchy or more diffuse infiltration may be observed, but the histology of the BM alone 
Table 3. B cell non-Hodgkin lymphomas in the bone marrow

\begin{tabular}{|c|c|c|c|c|}
\hline Subtype & Cytology & Morphology & Immunophenotype & Diagnostic clue \\
\hline SLL & Small and round nuclei & $\begin{array}{l}\text { Focal but occasionally } \\
\text { diffuse infiltration }\end{array}$ & $\begin{array}{l}\mathrm{CD}_{20}{ }^{+}, \mathrm{CD}_{5}^{+}, \mathrm{CD}_{23}{ }^{+} \\
\mathrm{BCL}_{2}{ }^{+}, \mathrm{CD}_{43}{ }^{+}\end{array}$ & $\begin{array}{l}\mathrm{BCL}^{+} \text {may cause } \\
\text { misdiagnosis of FL }\end{array}$ \\
\hline MCL & $\begin{array}{l}\text { Highly variable nuclei: } \\
\text { round, blastic or irregular }\end{array}$ & $\begin{array}{l}\text { Focal, paratrabecular } \\
\text { lesions }\end{array}$ & $\begin{array}{l}\text { Cyclin } \mathrm{D}^{+}, \mathrm{CD}_{20}{ }^{+} \\
\mathrm{FMC}_{7}^{+}, \mathrm{BCL}_{2}^{+} \\
\mathrm{CD}_{5}^{-}(10 \%)\end{array}$ & $\begin{array}{l}\text { Leukemic picture is } \\
\text { common }\end{array}$ \\
\hline FL & $\begin{array}{l}\text { Dense chromatin } \\
\text { with clefted nuclei }\end{array}$ & $\begin{array}{l}\text { Strikingly paratrabecular } \\
\text { pattern }\end{array}$ & $\mathrm{CD}_{20}{ }^{+}, \mathrm{CD}_{10}{ }^{+}, \mathrm{BCL}_{2}{ }^{+}$ & $\begin{array}{l}\text { Discordancy between } \\
\mathrm{BM} \text { and LN lesions } \\
\text { is common }\end{array}$ \\
\hline SMZL & $\begin{array}{l}\text { Various cell size } \\
\text { spectrum }\end{array}$ & Mixed patterns & $\begin{array}{l}\text { Variable, usually } \\
\mathrm{BCL} 2^{+}, \mathrm{CIG}^{+}\end{array}$ & $\begin{array}{l}\text { Leukemic picture is } \\
\text { common }\end{array}$ \\
\hline Other MZL & Variable & Mixed patterns & $\begin{array}{l}\text { No distinctive feature, } \\
\mathrm{BCL} 2^{+}\end{array}$ & $\begin{array}{l}\text { Infiltrates may be } \\
\text { occult }\end{array}$ \\
\hline LPL & Plasmacytoid lymphocytes & $\begin{array}{l}\text { Mixed patterns and } \\
\text { common Dutcher bodies }\end{array}$ & $\begin{array}{l}\mathrm{CIG}^{+}, \text {monoclonal } \\
\text { plasma cells }\end{array}$ & $\begin{array}{l}\text { Rouleaux formation } \\
\text { is sometimes observed } \\
\text { on PB smear }\end{array}$ \\
\hline $\begin{array}{l}\text { DLBCL } \\
\text { and variants }\end{array}$ & Large lymphoid cells & $\begin{array}{l}\text { Mixed patterns } \\
\text { Rarely distinctive } \\
\text { intravascular pattern }\end{array}$ & $\begin{array}{l}\text { Clonal IGH, BCL2 }{ }^{+/} \text {, } \\
\text { BCL6 }^{+}\end{array}$ & $\begin{array}{l}\text { Morphology may be } \\
\text { discordant with EM sites }\end{array}$ \\
\hline $\mathrm{BL}$ & $\begin{array}{l}\text { Intermediate sized } \\
\text { cells with basophilic } \\
\text { cytoplasm }\end{array}$ & $\begin{array}{l}\text { Leukemic pattern } \\
\text { mixed with normal } \\
\text { hematopoietic cells }\end{array}$ & $\begin{array}{l}\mathrm{CD}_{43}{ }^{+}, \mathrm{BCL}_{2}{ }^{-} \text {, sometimes } \\
\mathrm{EBER}^{+/-}\end{array}$ & \\
\hline B-LL & Variable size & $\begin{array}{l}\text { Leukemic } \\
\text { interstitial pattern }\end{array}$ & $\begin{array}{l}\text { Weak CD } 45^{+}, \mathrm{CD}_{34^{+}}, \mathrm{TdT}^{+}, \\
\mathrm{CD}_{10}{ }^{+}\end{array}$ & $\begin{array}{l}\text { Extent of BM involvement } \\
\text { is less than } 25 \%\end{array}$ \\
\hline
\end{tabular}

Table 4. T cell non-Hodgkin lymphoma in bone marrow

\begin{tabular}{|c|c|c|c|c|}
\hline Subtype & Cytology & Morphology & Immunophenotype & Diagnostic clue \\
\hline ALTL & $\begin{array}{l}\text { Large pleomorphic } \\
\text { immunoblasts with } \\
\text { plasma cell infiltration }\end{array}$ & $\begin{array}{l}\text { Heterogenous cell } \\
\text { infiltration with } \\
\text { hematopoietic hyperplasia }\end{array}$ & $\begin{array}{l}\text { Mature T cell phenotype } \\
\text { with } \mathrm{CD}_{4}^{+}, \mathrm{CD}_{10}^{+}, \\
\mathrm{PD} 1 \text {, and } \mathrm{CXCL} 13\end{array}$ & $\begin{array}{l}\text { Neoplastic T cells } \\
\text { with EBER }{ }^{-}, \mathrm{BCL6}^{+}, \mathrm{CD}_{3}{ }^{+} \\
\text {suggest } \mathrm{HL}\end{array}$ \\
\hline PTCL-NOS & $\begin{array}{l}\text { Variable with } \\
\text { predominance of large, } \\
\text { atypical lymphoid cells }\end{array}$ & $\begin{array}{l}\text { Pleomorphic neoplastic } \\
\text { cells admixed with } \\
\text { reactive cells }\end{array}$ & $\begin{array}{l}\text { Usually } \mathrm{CD}_{4}^{+} \text {, loss } \\
\text { of pan-T cell Ags } \\
\text { with clonal TCR }\end{array}$ & $\begin{array}{l}\text { Neoangiogenesis and } \\
\text { reticulin fibrosis is } \\
\text { common }\end{array}$ \\
\hline $\mathrm{ALCL}, \mathrm{ALK}^{+}$ & $\begin{array}{l}\text { Small to large } \\
\text { pleomorphic cells }\end{array}$ & $\begin{array}{l}\text { Individual tumor } \\
\text { cells maybe occult and } \\
\text { may resemble RS cells }\end{array}$ & $\begin{array}{l}\text { Mature T cell } \\
\text { phenotype with } \mathrm{CD}_{30^{+}} \\
\mathrm{TIA}^{+}, \text {nucelus } \mathrm{ALK}^{+} \\
\text {and } \mathrm{EBV}^{-}\end{array}$ & $\begin{array}{l}\text { Leukemic presentation } \\
\text { is more common in } \\
\text { children }\end{array}$ \\
\hline T-LL & Blastic cells & $\begin{array}{l}\text { Blastic cells with scant } \\
\text { cytoplasm }\end{array}$ & $\begin{array}{l}\text { Immature T cell } \\
\text { phenotype }\end{array}$ & $\begin{array}{l}\text { Extent of BM involvement } \\
\text { is less than } 25 \%\end{array}$ \\
\hline
\end{tabular}

ALTL, anaplastic large T cell lymphoma; HL, Hodgkin lymphoma; PTCL-NOS, peripheral T cell lymphoma, not otherwise specified; Ag, antigen; ALCL, anaplastic large cell lymphoma; ALK, anaplastic lymphoma kinase; T-LL, T-lymphoblastic lymphoma; BM, bone marrow. 
is usually not diagnostic [18].

LPL is most often encountered in the presence of the clinical syndrome of Waldenstrom's macroglobulinemia, with the presence of an IgM paraprotein and BM involvement. Histologically, the BM shows variably distributed, often interstitial and diffuse patterns of small lymphocytes, lymphoplasmacytoid cells, and plasma cells with variable fibrosis [16].

\section{High-grade $\mathrm{B}$ cell $\mathrm{NHL}$}

Diffuse large-cell B cell lymphoma (DLBCL) has a low $\mathrm{f}$ requency of $\mathrm{BM}$ infiltration and the patterns of infiltration are highly variable, ranging from subtle, focal infiltrates to a packed marrow with complete replacement of hematopoiesis [16]. The BM is infiltrated by a heterogeneous cell population, including large neoplastic cells with vesicular nuclei, prominent nucleoli, basophilic cytoplasm, and frequent mitotic figures. The tumor cells may express germinal center-type immunophenotypes, such as $\mathrm{CD}_{1} \mathrm{o}^{+}$or $\mathrm{CD} 1 \mathrm{O}^{-} / \mathrm{BCL6}^{+} / \mathrm{MUMr}^{-}$, or activating $\mathrm{B}$ cell-like (non-germinal center)-type, such as $\mathrm{CD}^{-} / \mathrm{BCL6}^{+} / \mathrm{MUM1}^{+}$or $\mathrm{CD}^{-} \mathrm{O}^{-} / \mathrm{BCL6}^{-}[19,2 \mathrm{O}]$. So-called discordant infiltrates, meaning small neoplastic cells in BM with DLBCL at another site, have been reported to be associated with a better prognosis than concordant BM infiltration [21].

T-cell/histiocyte-rich large B-cell lymphoma (TCRB$\mathrm{CL}$ ) is another distinctive type of DLBCL with unique features in the BM. Similar to extramedullary disease, BM infiltrates in TCRBCL show a predominance of non-neoplastic T cells and variable numbers of histiocytes. Neoplastic large B cells are typically infrequent and overall morphological features overlap with peripheral T cell lymphoma (PTCL) and Hodgkin lymphoma. The $\mathrm{CD}_{20} \mathrm{O}^{+}, \mathrm{EMA}^{+}, \mathrm{CD}_{30^{-}}$, and $\mathrm{CD}_{15}{ }^{-}$phenotype of the neoplastic large cells helps to distinguish TCRBCL from Hodgkin's lymphoma [12,17].

$\mathrm{BM}$ involvement in Burkitt lymphoma (BL) ranges from scattered interstitial foci to complete replacement of the normal marrow elements by medium-sized blasts with inconspicuous nucleoli, basophilic cytoplasm, and sometimes, a "starry sky" pattern, due to numerous mitotic figures. Necrosis is frequent [18]. BL shows a mature B cell phenotype with coexpression of surface IgM, CD2O, CD10, and BCL6, but lacks CD5, BCL2, and TdT [12].

B-LL and leukemia are biologically related disorders that differ only in terms of disease distribution. B-LLs predominate outside the BM and cases with $<25 \%$ $\mathrm{BM}$ infiltration are arbitrarily designated lymphomas, whereas cases with $>25 \%$ neoplastic cells in the BM are termed leukemias [12]. BM involvement in B-LL shows patchy interstitial infiltrates of lymphoblasts and this may be morphologically subtle due to their admixture with normal hematopoietic cells. Immunohistochemical staining and flow cytometric immunophenotyping may be essential to detect occult neoplastic cells. The neoplastic lymphoblasts are slightly larger than lymphocytes, with round or convoluted nuclei, fine chromatin, inconspicuous nucleoli, and scant, faintly basophilic cytoplasm. Mitotic figures are common. The blasts usually pack the marrow spaces but occasionally infiltrate patchily. Lymphoblasts are strongly reactive for TdT and $\mathrm{CD}_{34}$ immunohistochemical stains. In addition to typical B cell markers, B-LLs are frequently positive for CD10 $[17,18]$.

\section{T cell NHLs}

Neoplastic T cells frequently produce systemically acting cytokines. The BM may be the site of a cytokine response even in cases in which the lymphoma itself does not involve the BM. Indeed, florid BM hemophagocytic syndromes often result from systemic cytokine-mediated histiocyte activation [12].

Angioimmunoblastic T cell lymphoma (AITL) in BM shows polymorphic, sparsely admixed, large atypical cells in a background of abundant non-neoplastic cells. Increased neoangiogenesis and reticulin fibrosis are common, but characteristic arborizing vasculature in the lymph node is rarely observed. The presence of large, transformed, EBV-positive B cells in the infiltrate may point to a diagnosis of AITL, but can also lead to confusion with TCFBCL or Hodgkin lymphoma [16]. The tumor cells are usually reactive to immunohistochemical staining for $\mathrm{CD}_{2}, \mathrm{CD}_{3}, \mathrm{CD}_{4}, \mathrm{CD}_{5}, \mathrm{CD}$, and $\mathrm{CD}_{10}$. $\mathrm{PD} 1$ and CXCL13 are also expressed in neoplastic T cells. However, detection of $\mathrm{CD}_{10} \mathrm{O}^{+}$neoplastic cells in $\mathrm{BM}$ can be difficult, and the diagnosis of AITL usually requires a biopsy of an extramedullary lesion, particularly a lymph node $[12,18]$.

In BM involvement in PTCL not otherwise specified (NOS), interstitial or paratrabecular infiltration is common. The infiltration is polymorphic, similar to an 
extramedullary lesion, with variable numbers of small, medium, and large neoplastic lymphoid cells admixed with eosinophils and histiocytes, which may mask the underlying lymphoma. Occasional Reed-Sternberg-like cells may be present [17]. Because BM involvement in PTCL-NOS is observed in up to $40 \%$ of cases, a careful examination is required. Although discrete foci predominate, subtle interstitial infiltrates may be encountered, which can be overlooked in a morphological review, and thus immunohistochemistry is essential in such cases. Immunohistochemically, the neoplastic lymphoid cells are usually positive for $\mathrm{T}$ cell markers such as $\mathrm{CD}_{3}, \mathrm{CD} 2$, $\mathrm{CD}_{5}$, and $\mathrm{CD}_{7}$. However, some $\mathrm{T}$ cell markers may be aberrantly deleted. Sometimes, it can be difficult to decide whether the $\mathrm{T}$ cells are truly neoplastic in interstitial involvement in T cell lymphoma even with molecular and/or immunohistochemical studies [18].

Anaplastic large lymphoma cells in BM core biopsy sections are often dispersed individually among benign hematopoietic cells [16]. Large neoplastic cells with abundant cytoplasm, large pleomorphic kidney-shaped nuclei, and multiple, prominent eosinophilic nucleoli grow in a cohesive pattern. Immunohistochemical assessments of $\mathrm{CD}_{3} \mathrm{O}$ and anaplastic lymphoma kinase are essential for detecting morphologically subtle infiltrates [12].

Although mycosis fungoides rarely involves the BM, even in patients with advanced disease or Sézary syndrome, helper T cells with small, convoluted, or cerebriform nuclei can infiltrate the BM with no characteristic pattern. Immunohistochemically, they are positive for $\mathrm{CD}_{2}, \mathrm{CD}_{3}, \mathrm{CD}_{5}, \mathrm{CD} 7$ (in $~ 30 \%$ of cases), and $\mathrm{CD}_{4}$, and negative for $\mathrm{CD}_{25}$ [12].

$\mathrm{BM}$ in acute lymphoblastic leukemia/lymphoma of $\mathrm{T}$ cell origin is morphologically similar to B-LL/leukemia, typically characterized by a massive, diffuse infiltrate of monomorphic blasts with greatly reduced hematopoiesis. Immunohistochemistry for TdT, which is usually strongly positive in the nuclei of blasts, CD99, $\mathrm{CD}_{3}$, CDIa, and $\mathrm{T}$ cell markers can aid the determination of the cell lineage and help discriminate it from other neoplasms [16].

\section{Hodgkin lymphoma}

$\mathrm{BM}$ involvement in Hodgkin lymphoma is uncommon; it is seen in only $5 \%$ of patients $[22,23]$. For a reliable mor- phological evaluation, generous BM trephine biopsy specimens of 1 to $2 \mathrm{~cm}$ in length and multiple-step sectioning are required. The histological features of Hodgkin lymphoma subtypes are usually indistinguishable. Focal fibrosis and abnormal mononuclear cells may be a diagnostic clue, but classic Reed-Sternberg cells may not be present [24]. The neoplastic cells in classic Hodgkin lymphoma are immunohistochemically positive for $\mathrm{CD}_{30}$ and $\mathrm{CD}_{15}$, and negative for $\mathrm{CD}_{45}$ and $\mathrm{CD}_{2} \mathrm{O}$. The lymphocytic and/or histiocytic cells of nodular lymphocyte-predominant Hodgkin lymphoma are $\mathrm{CD}_{2} \mathrm{O}^{+}$, $\mathrm{CD}_{30}{ }^{-}$, and $\mathrm{CD}_{15}-[17,18]$.

\section{Recommendations for immunohistochemical pro- files for the evaluation of BM involvement in lym- phoma}

A BM biopsy is considered positive for lymphoma involvement in the presence of lymphoid substitution of normal BM hematopoietic cells; the percentage of BM involvement is calculated as the extent of the lymphoid population versus the whole BM cellularity, and the patterns of infiltration are known and immunohistochemistry profiles can be applied according to the morphology of neoplastic lymphoid cells or a pathological diagnosis at extranodal sites (Table 5).

There are some diagnostic challenges in the evaluation of BM in patients with lymphoma. The first issue is the distinction between reactive nodular lymphoid infiltrates and nodular infiltrates of the lymphoma. This is a common diagnostic problem in BM trephines in patients with low-grade lymphomas. Such reactive infiltrates can be found in various disorders, including aging, autoimmune diseases, infections, and myeloproliferative neoplasms. A more mixed cellular composition, well-defined borders, an intertrabecular location, a low number of infiltrates, and the absence of reticulin fibrosis are morphological features that are more commonly found in benign lymphoid nodules. Germinal centers are relatively rare in benign infiltrates. Immunophenotyping usually shows a predominance of $\mathrm{T}$ cells and a lack of aberrant markers and immunoglobulin light chain restriction $[16]$.

Second, in cases of aberrant expression in nodal lesions, aberrantly expressed antigens can provide diagnostic clues for evaluating the BM. Peripheral T cell lymphoma is a typical example of this; most peripheral 
Table 5. Recommendation of immunohistochemistry profiles for the evaluation of bone marrow involvement of lymphoma

\begin{tabular}{|c|c|}
\hline Diffuse large B cell lymphoma & $\mathrm{CD}_{3}, \mathrm{CD} 20, \mathrm{CD}_{5}, \mathrm{CD} 10, \mathrm{BCL} 6, \mathrm{MUM}-1$ (presence of nodule:Ki-67) \\
\hline Follicular lymphoma & $\mathrm{CD}_{3}, \mathrm{CD} 10, \mathrm{CD} 20, \mathrm{BCL6}, \mathrm{MUM}-1$ \\
\hline Mantle cell lymphoma & $\mathrm{CD}_{3}, \mathrm{CD}_{5}, \mathrm{CD} 20, \mathrm{CD} 79 \mathrm{a}$, Cyclin D1 \\
\hline MALToma & $\mathrm{CD}_{3}, \mathrm{CD} 79 \mathrm{a}, \mathrm{CD} 20, \mathrm{BCL} 6$ (presence of nodule:Ki-67) \\
\hline Burkitt lymphoma & $\begin{array}{l}\text { Oil red O on aspiration smear } \\
\text { CD10, CD20, BCL6, CD } 3 \text { (presence of nodule:Ki-67) }\end{array}$ \\
\hline Lymphoblastic lymphoma & $\mathrm{CD}_{3}, \mathrm{CD}_{5}, \mathrm{TdT}, \mathrm{CD}_{2} \mathrm{O}, \mathrm{PAX}_{-5}, \mathrm{CD}_{34}$ \\
\hline Angioimmunoblastic T cell lymphoma & $\mathrm{CD}_{2}, \mathrm{CD}_{3}, \mathrm{CD}_{5}, \mathrm{CD} 10, \mathrm{CD} 21, \mathrm{CD}_{34}$ \\
\hline Peripheral T cell lymphoma & $\mathrm{CD}_{2}, \mathrm{CD}_{3}, \mathrm{CD}_{5}, \mathrm{CD}_{4}, \mathrm{CD} 8, \mathrm{CD} 20, \mathrm{CD}_{79 \mathrm{a}}$ \\
\hline Anaplastic large cell lymphoma & $\mathrm{CD}_{3}, \mathrm{CD}_{5}, \mathrm{CD}_{15}, \mathrm{CD}_{30}, \mathrm{CD}_{45}, \mathrm{CD}_{2}, \mathrm{CD} 20, \mathrm{ALK}-1$ \\
\hline NK/T cell lymphoma & $\mathrm{CD}_{2}{ }^{+}, \mathrm{CD}_{5} 6^{+}, \mathrm{sCD}_{3}{ }^{-}, \mathrm{cCD}_{3} \mathrm{e}^{+}, \mathrm{CD}_{4}{ }^{-}, \mathrm{CD}_{5}{ }^{-}, \mathrm{CD}^{-}, \mathrm{EBER}^{+}$, granzyme $^{+}, \mathrm{TIA}^{+}$ \\
\hline
\end{tabular}

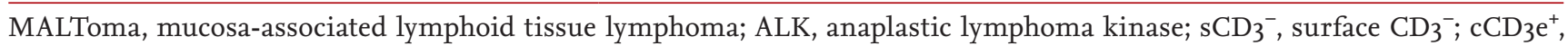
cytoplasmic $\mathrm{CD}_{3} \mathrm{e}^{+}$.

T cell lymphoma patients present with aberrant expression in peripheral lymph nodes. This is usually characterized by downregulation of $\mathrm{CD}_{5}$ and $\mathrm{CD}_{7}$, with a predominant $\mathrm{CD}_{4}+\mathrm{CD} 8^{-}$phenotype. $\mathrm{CD} 4 / \mathrm{CD} 8$ double positivity or double negativity is sometimes seen in the absence of a follicular $\mathrm{T}$ helper cell phenotype $\left(\mathrm{CD}_{10} \mathrm{O}^{+}\right.$, $\mathrm{BCL6}^{+}, \mathrm{PDi}^{+}$, and $\left.\mathrm{CXCL1}_{3}{ }^{+}\right)$. Aberrant expression of $\mathrm{CD} 20, \mathrm{CD} 79 \mathrm{a}$, and/or $\mathrm{CD}_{30}$ have also occasionally been observed [25].

\section{ROLE OF FLOW CYTOMETRY}

Flow cytometry is useful and may be essential for the diagnosis of leukemic manifestations of a lymphoma. The leukemic phase indicates lymphoma cells $\geq 25 \%$ among nucleated cells in the peripheral blood or BM aspirate [25]. Usually, lymphoma cells are gated as CD$45^{\text {bright}} /$ side-scattered light (SSC) $)^{\text {low }}$ by flow cytometry, but immature lymphoid cells are $\mathrm{CD}_{4} 5^{\text {intermediate }}$ or negative, $\mathrm{TdT}^{+}$, and $\mathrm{CD}_{34} 4^{+}$. The lineage markers on lymphocytes are $\mathrm{CD}_{19}$ for the $\mathrm{B}$ cell lineage, $\mathrm{CD}_{3}$ for the $\mathrm{T}$ cell lineage, and $\mathrm{CD}_{5} 6$ for the NK cell lineage. According to European LeukemiaNet, the B-oriented panel includes $\mathrm{CD}_{1}{ }^{+}$cells with other markers such as $\mathrm{CD}_{5}$, $\mathrm{CD} 20, \mathrm{CD}_{22}, \mathrm{CD}_{23}, \mathrm{CD} 103, \mathrm{CD} 10, \kappa$ and $\lambda$ light chains, surface Ig, CD25, CD79b, and $\mathrm{CD}_{3} 8$; the T-oriented panel includes $\mathrm{CD}_{3}{ }^{+}$cells with other markers such as $\mathrm{CD} 2$, $\mathrm{CD}_{4}, \mathrm{CD}_{5}, \mathrm{CD} 8$, and $\mathrm{CD}_{7}$; and the NK-oriented panel includes $\mathrm{CD}_{5} 6^{+}$cells with other markers such as $\mathrm{CD}_{1} 6$,
$\mathrm{CD}_{57}, \mathrm{CD}_{45}$, CD158, CD94, and cytotoxic granule-associated proteins (TIA-1, granzyme-B, perforin) as an activated cytotoxic phenotype [26]. Analyses of leukemic BM involvement in Korean patients with NHL have shown that the leukemic phase is associated with a poor prognosis, such as low complete remission, low 5-year survival rate, and a high death rate [27].

Recently, EuroFlow suggested eight-colored antibody panels for standardized n-dimensional flow cytometric immunophenotyping of normal, reactive, and malignant leukocytes. The lymphoid screening tube detects aberrant mature lymphocyte populations of $\mathrm{B}, \mathrm{T}$, and NK lineages, but this eight-color tube does not allow the precise diagnosis and classification of the aberrant lymphocyte populations detected. This needs further characterization with plasma cell dyscrasia, B-chronic lymphoproliferative disease (B-CLPD), T-CLPD, and NK-CLPD panels [28].

In February 2006, the Korean Society of Diagnostic Hematology recommended a minimum antibody panel for the diagnosis and classification of CLPDs [29]. Recently, this recommendation was modified, considering recent progress in the flow cytometric analysis of lymphoid malignancies (Table 6). After gating on $\mathrm{CD}_{45} 5^{\text {bright }} /$ SSC low, combinations of $\kappa / \lambda / \mathrm{CD}_{20}$ (or $\left.\mathrm{CD}_{19}\right) / \mathrm{CD}_{45}, \mathrm{CD}_{5} /$ $\mathrm{CD} 10 / \mathrm{CD}_{20}$ (CD19)/CD45, or CD4/CD8/CD3 (CD7)/ CD 45 are useful for the interpretation of flow cytometric results. For example, because a mature B cell lymphoma shows immunoglobulin light chain restriction, the antibody combination of $\kappa / \lambda / \mathrm{CD}_{19}$ (or $\mathrm{CD}_{20}$ )/CD45 is useful. 
Table 6. Minimum antibody panel for diagnosis of chronic lymphoproliferative diseases

\begin{tabular}{|c|c|c|c|}
\hline & B-lineage & T-lineage & Others \\
\hline \multirow[t]{8}{*}{ First step } & CDio & Cytoplasmic $\mathrm{CD}_{3}$ & $\mathrm{CD}_{45}$ \\
\hline & $\mathrm{CD}_{19}$ & Surface $\mathrm{CD}_{3}$ & $\mathrm{TdT}$ \\
\hline & $\mathrm{CD} 20$ & $\mathrm{CD} 2$ & $\mathrm{CD}_{5} 6$ \\
\hline & Surface CD22 & $\mathrm{CD}_{5}$ & \\
\hline & $\mathrm{CD}_{23}$ & $\mathrm{CD}_{7}$ & \\
\hline & $\mathrm{FMC}_{7}$ & $\mathrm{CD}_{5} 6$ & \\
\hline & $\kappa$ & & \\
\hline & $\lambda$ & & \\
\hline \multirow[t]{5}{*}{ Second step } & CDi1c & $\mathrm{CD}_{4}$ & $\mathrm{CD} 16$ \\
\hline & $\mathrm{CD} 25$ & CD8 & $\mathrm{CD}_{57}$ \\
\hline & $\mathrm{CD}_{13} 8\left(\mathrm{CD}_{3} 8\right)$ & & \\
\hline & CD103 & & \\
\hline & Cyclin Dı & & \\
\hline
\end{tabular}

Table 7. Immunophenotypes of B cell lymphoid malignancies

\begin{tabular}{lccccccccc}
\hline & Pan-B & sIg type & CD & CD22 & CD23 & FMC7 & CD10 & CD11c & CD 25 \\
\hline CLL & + & $\operatorname{IgM} / \mathrm{D}(\mathrm{w})$ & + & $+(\mathrm{w})$ & + & - & - & $-/+(\mathrm{w})$ & $-/+(\mathrm{w})$ \\
$\mathrm{MCL}$ & + & $\operatorname{IgM} / \mathrm{D}(\mathrm{s})$ & + & $+(\mathrm{w})$ & - & + & $-/+$ & - & $-/+(\mathrm{w})$ \\
$\mathrm{B}-\mathrm{PLL}$ & + & $\operatorname{IgM}(\mathrm{s})$ & - & $+(\mathrm{s})$ & -+ & + & - & $-/+(\mathrm{w})$ & $-/+(\mathrm{w})$ \\
$\mathrm{FL}$ & + & $\operatorname{IgM}(\mathrm{s})$ & - & $+(\mathrm{w})$ & -++ & $-/+$ & + & - & $-/+(\mathrm{w})$ \\
$\mathrm{HCL}$ & + & $\operatorname{IgM} / \mathrm{G} / \mathrm{A}$ & - & $+(\mathrm{s})$ & - & + & $-/+$ & $+(\mathrm{s})$ & $+(\mathrm{s})$ \\
SMZL & + & $\operatorname{IgM} / \mathrm{G}$ & - & $+(\mathrm{s})$ & - & + & - & $+(\mathrm{s})$ & - \\
LPL/WM & + & $\operatorname{IgM}(\mathrm{s})$ & - & $+(\mathrm{w})$ & $-/+$ & - & - & - & $-/+(\mathrm{w})$ \\
\hline
\end{tabular}

Pan-B, CD19, CD2o, sIg; sIg, surface immunoglobulin; CLL, chronic lymphocytic leukemia; IgM, immunoglobulin M; (w), weak fluorescence intensity; MCL, mantle cell lymphoma; (s), strong fluorescence intensity; B-PLL, B-prolymphocytic leukemia; FL, follicular lymphoma; HCL, hairy cell leukemia; SMZL, splenic B cell marginal zone lymphoma; LPL/WM, lymphoplasmacytoid lymphoma/Waldenstrom macroglobulinemia.

To see aberrant antigen expression, the combination of $\mathrm{CD}_{5} / \mathrm{CD}_{10} / \mathrm{CD}_{19}$ (or $\mathrm{CD}_{20}$ )/CD45 is also useful. In the panel of $\mathrm{CD}_{5} / \mathrm{CD}_{10} / \mathrm{CD}_{19}$ (or $\mathrm{CD}_{20}$ )/CD45, after the serial gating of $\mathrm{CD}_{4} 5^{\text {+bright/low }}$ and $\mathrm{CD} 19$ (or $\left.\mathrm{CD}_{20}\right)^{+}$gating, the flow cytometric cytograms of $\mathrm{CD}_{5}^{+} \mathrm{CD}_{10}^{-}, \mathrm{CD}_{5}^{-} \mathrm{CD}_{10}{ }^{+}$, $\mathrm{CD}_{5}{ }^{+} \mathrm{CD}_{10} 0^{+}$, and $\mathrm{CD}_{5}^{-} \mathrm{CD}_{10}^{-}$patterns indicate specific subtypes of mature B cell lymphomas. Mature T\&NK cell lymphomas frequently show aberrant $\mathrm{T}$ cell antigen expression, such as a lack of pan- $T$ antigens ( $\left.\mathrm{CD}_{5}, \mathrm{CD}_{7}\right)$. To identify the restricted populations of T cells, the antibody combination of $\mathrm{CD}_{4} / \mathrm{CD} 8 / \mathrm{CD}_{3} / \mathrm{CD}_{4} 5$ is used, and serial gating of $\mathrm{CD}_{4} 5^{\text {tbright/low }}$ and $\mathrm{CD}_{3}{ }^{+}$identify specific subtypes of mature T\&NK cell lymphomas such as $\mathrm{CD}_{4}^{+}$
$\mathrm{CD} 8^{-}, \mathrm{CD}_{4}^{-} \mathrm{CD}^{+}, \mathrm{CD}_{4}^{+} \mathrm{CD}^{+}$, and $\mathrm{CD}_{4}^{-} \mathrm{CD} 8^{-}$patterns. The immunophenotypes of the specific subtypes of lymphoid malignancies are summarized in Tables 7 and 8.

\section{ROLE OF CYTOGENETIC ANALYSES}

Cytogenetic analyses can provide important information for discriminating lymphomatous BM and predicting prognoses in certain types of lymphoma. For example, del(11q) or del(17p) in CLL indicate a worse prognosis, and thus aggressive treatment such as allogeneic stem cell transplantation should be considered ear- 
Table 8. Immunophenotypes of $\mathrm{T}$ cell and NK cell lymphoid malignancies

\begin{tabular}{|c|c|c|c|c|c|c|c|c|c|c|}
\hline & $\mathrm{CD}_{3}$ & $\mathrm{CD}_{4}$ & CD8 & $\mathrm{CD}_{7}$ & $\mathrm{CD}_{5}$ & $\mathrm{CD} 2$ & $\mathrm{CD} 25$ & $\mathrm{CD}_{5} 6$ & $\mathrm{CD}_{16} 6$ & $\mathrm{CD}_{57}$ \\
\hline T-PLL & + & + & $-1+$ & + & + & + & - & - & - & - \\
\hline T-LGL & + & - & + & $-1+$ & $-1+$ & + & - & - & + & + \\
\hline ATLL & + & + & - & - & + & + & ++ & - & - & - \\
\hline Agg NK & + & - & $-1+$ & - & - & + & - & + & - & - \\
\hline ENK/T, nasal & + & - & $-1+$ & - & - & + & - & + & - & - \\
\hline HSTL & + & - & $+1-$ & + & - & + & - & + & - & - \\
\hline $\mathrm{MF} / \mathrm{SS}$ & + & + & $-1+$ & $-1+$ & $+1-$ & + & - & - & - & - \\
\hline AITL & + & + & - & + & + & + & - & - & - & - \\
\hline PTCL, NOS & + & $+1-$ & $-1+$ & $-1+$ & $-1+$ & + & - & - & - & - \\
\hline ALCL, ALK+ & $-1+$ & $+1-$ & $-1+$ & $-1+$ & $+/-$ & $+1-$ & ++ & $+1-$ & - & - \\
\hline ALCL, ALK- & $-1+$ & $+/-$ & $-1+$ & $-1+$ & $+/-$ & $+1-$ & ++ & $+1-$ & - & - \\
\hline
\end{tabular}

T-PLL, T-prolymphocytic leukemia; T-LGL, T-large granular lymphocyte leukemia; ATLL, adult T cell leukemia/lymphoma; Agg NK, aggressive NK leukemia; ENK/T, extranodal NK/T cell lymphoma; HSTL, hepatosplenic T cell lymphoma; MF/SS, mycosis fungoides/Sezary syndrome; AITL, angioimmunoblastic T cell lymphoma; PTCL-NOS, peripheral T cell lymphoma, not otherwise specified; ALCL, anaplastic large cell lymphoma; ALK, anaplastic lymphoma kinase.

Table 9. Types of probe for fluorescence in situ hybridization

\begin{tabular}{ll}
\hline Lymphoma subtypes & \multicolumn{1}{c}{ FISH probe } \\
\hline $\begin{array}{l}\text { Chronic lymphocytic } \\
\text { leukemia }\end{array}$ & $\operatorname{del}(11 \mathrm{q}), \operatorname{del}(17 \mathrm{p}), \mathrm{t}(11 ; 14)$ \\
Follicular lymphoma & $\mathrm{t}(14 ; 18)$, BCL6 break apart \\
Mantle cell lymphoma & $\mathrm{t}(11 ; 14)$ \\
Burkitt lymphoma & $\mathrm{t}(8 ; 14)$ and MYC break apart \\
Gastric MALT lymphoma & $\mathrm{t}(11 ; 18)$ \\
\hline
\end{tabular}

FISH, fluorescence in situ hybridization; MALT, mucosa-associated lymphoid tissue.

ly in the course of therapy. Fluorescence in situ hybridization (FISH) is particularly useful for detecting clonal lymphoma cells in BM. Types of probes for FISH that are validated and of clinical importance are summarized in Table 9.

\section{ISSUES TO BE INVESTIGATED}

Currently, a pathological examination does not assess the whole BM and the interpretation of a BM specimen usually requires a highly experienced hematopathologist. Although the revised response criteria for malignant lymphoma, published in 2007 , indicates that uninvolved BM should be normal histologically with a small
(<2\%) clonal B cell population detected by flow cytometry [30], there are still some diagnostic challenges.

First, the differential diagnosis of reactive lymphoid infiltrates from nodular infiltrates of low-grade lymphomas remains a common problem. Although some diagnostic clues based on morphology have been suggested $[16,31]$, some cases may remain unresolved. To clarify this uncertainty, molecular studies using DNAor RNA-based polymerase chain reaction should be considered. Although this technique still does not cover the whole range of problems, it should be considered whether some proven tests, such as immunoglobulin heavy chain gene rearrangement analysis and $\mathrm{T}$ cell receptor analysis, should be involved in the standard. The next issue associated with BM morphology concerns the clinical meaning of concordance with the morphology of the lymphoma cells in the lymph node. In patients with DLBCL, some have shown infiltrates of small B cell lymphoma cell in BM, instead of large B cells (discordant involvement). Under this condition, it is presumed that DLBCL developed as a transformation from an occult small B cell lymphoma, or alternatively, two unrelated lymphomas are present [21]. Recently, it has been reported that in multivariate analyses, including individual factors of the IPI system, concordant BM involvement has an independently negative impact on prognosis whereas discordant BM involvement does 
not [32]. If this can be validated in a prospective cohort, the morphology of lymphoma cells in BM involvement should be considered when predicting prognosis in patients with DLBCL.

Another issue is flow cytometry analyses. As mentioned above, flow cytometry is essential when assessing BM involvement. Current guidelines regard a small clonal population $(<2 \%)$ as uninvolved BM [30]. However, to the best of our knowledge, no clinical study has addressed this issue. Moreover, recent advances in flow cytometry technology have caused a wide range of variation in the sensitivity of flow cytometric analyses among institutions. Thus, it is desirable to document the minimal criteria for flow cytometry technology in a standard guideline. The last issue in flow cytometry is the meaning of discordance between a bone marrow biopsy (BMB) and flow cytometry. Recently, in a study that included 757 NHL patients, there was considerable discordance between BMB and flow cytometry [33]. For example, in FL and LPLs, the discordance rates were up to $22 \%$ and $24 \%$, respectively. Based on BMB and flow cytometry results, four subsets can be created in patients with NHL: positive BMB and positive flow cytometry, positive $\mathrm{BMB}$ and negative flow cytometry, negative $\mathrm{BMB}$ and positive flow cytometry, and negative $\mathrm{BMB}$ and negative flow cytometry. To date, no study has analyzed the prognostic significance of each group. It could be valuable to investigate whether there are prognostic differences among these subgroups. Moreover, the relationship between prognosis and the degree of involvement remains unclear. Although some retrospective analyses have revealed significant correlations between degree of BM involvement and prognosis [34-37], this has not been validated. To clarify this issue, it is important to establish uniform criteria for quantifying the degree of BM involvement objectively, so as to minimize differences among interpreting pathologists.

Finally, we discuss whether BM status can be evaluated by clinical staging using CT, MRI, or PET-CT. Because of technical limitations of these imaging modalities, BM assessment is currently possible only by a pathological examination. Because a BM biopsy at multiple sites is impossible in routine clinical practice, hematopathologists and clinicians have accepted results from BM examinations at the iliac crest on the assumption that this area may reflect whole BM status. However, technical advances in imaging modalities have shown that this is not true. A recent prospective study that compared the performance of BMB, whole-body MRI, and PET-CT to evaluate lymphomatous BM invasion demonstrated that noninvasive morphological procedures could be superior to a pathological BM examination [38]. In that study, most patients with abnormal BM findings on MRI or PET-CT showed BM infiltration in areas other than the iliac crest. Recently, resolution and sequence protocols of MRI have made rapid progress, sufficient to detect lymphomatous BM invasion [39]. Usually, MRI is considered to have high sensitivity, but specificity may be suboptimal for assessing lymphomatous BM invasion [40]. Nevertheless, it is expected that ongoing advances in technical aspects will make it possible to assess BM status by imaging without a pathological exam. Moreover, it is considered that PET-MRI, a new, developing imaging modality combining PET and MRI, may be promising for $\mathrm{BM}$ evaluations and applicable in the near future [39].

\section{CONCLUSIONS}

BM involvement in patients with lymphoma provides important information in clinical practice. Despite the limitations of current BM evaluation methods, standardization of the BM evaluation process is important to improve patient care. Based on standardized protocols, discussions about how to define positive lymphomatous $\mathrm{BM}$ should be in progress. Furthermore, because recent technological advances in flow cytometry and imaging modalities are expected to impact clinical practice in the near future, interdepartmental collaboration including the areas of medicine, hematopathology, radiology, and nuclear medicine is more important than ever.

\section{Conflict of interest}

No potential conflict of interest relevant to this article was reported.

\section{Acknowledgments}

This work was supported by the Korean Society of Hematology Lymphoma Working Party. 


\section{REFERENCES}

1. Zhang QY, Foucar K. Bone marrow involvement by hodgkin and non-hodgkin lymphomas. Hematol Oncol Clin North Am 2009;23:873-902.

2. Carbone PP, Kaplan HS, Musshoff K, Smithers DW, Tubiana M. Report of the committee on Hodgkin's disease staging classification. Cancer Res 1971;31:1860-1861.

3. Lister TA, Crowther D, Sutcliffe SB, et al. Report of a committee convened to discuss the evaluation and staging of patients with Hodgkin's disease: Cotswolds meeting. J Clin Oncol 1989;7:1630-1636.

4. Hoppe RT, Advani RH, Ai WZ, et al. Hodgkin lymphoma. J Natl Compr Canc Netw 2011;9:1020-1058.

5. Zelenetz AD, Abramson JS, Advani RH, et al. NCCN clinical practice guidelines in oncology: non-Hodgkin's lymphomas. J Natl Compr Canc Netw 2010;8:288-334.

6. Bayraktar S, Bayraktar UD, Stefanovic A, Lossos IS. Primary ocular adnexal mucosa-associated lymphoid tissue lymphoma (MALT): single institution experience in a large cohort of patients. Br J Haematol 2011;152:72-80.

7. Oh SY, Kim WS, Kim JS, et al. Stage IV marginal zone B-cell lymphoma: prognostic factors and the role of rituximab. Consortium for Improving Survival of Lymphoma (CISL) study. Cancer Sci 2010;101:2443-2447.

8. Thieblemont C, Berger F, Dumontet C, et al. Mucosa-associated lymphoid tissue lymphoma is a disseminated disease in one third of 158 patients analyzed. Blood 2000; 95:802-806.

9. The International Non-Hodgkin's Lymphoma Prognostic Factors Project. A predictive model for aggressive non-Hodgkin's lymphoma. N Engl J Med 1993;329:987994.

10. Stiff PJ, Unger JM, Cook JR, et al. Autologous transplantation as consolidation for aggressive non-Hodgkin's lymphoma. N Engl J Med 2013;369:1681-1690.

11. Yoon JH, Kim JW, Jeon YW, et al. Role of frontline autologous stem cell transplantation in young, high-risk diffuse large B-cell lymphoma patients. Korean J Intern Med 2015;30:362-371.

12. Foucar K, Reichard K, Czuchlewski D. Bone Marrow Pathology. 3rd ed. Chicago: American Society for Clinical Pathology Press, 2010.

13. Rozman C, Montserrat E. Chronic lymphocytic leukemia. N Engl J Med 1995;333:1052-1057.

14. Montserrat E, Villamor N, Reverter JC, et al. Bone marrow assessment in B-cell chronic lymphocytic leukaemia: aspirate or biopsy? A comparative study in 258 patients. Br J Haematol 1996;93:111-116.

15. Jeon YW, Cho SG. Chronic lymphocytic leukemia: a clinical review including Korean cohorts. Korean J Intern Med 2016;31:433-443.

16. Fend F, Kremer M. Diagnosis and classification of malignant lymphoma and related entities in the bone marrow trephine biopsy. Pathobiology 2007;74:133-143.

17. Foucar K, Reichard K, Wilson C, et al. Diagnostic Pathology: Blood and Bone Marrow. Salt Lake City: Amirsys Pub., 2012.

18. Brown D, Gatter K, Natkunam Y, Warnke R. Bone Marrow Diagnosis: An Illustrated Guide. Malden: Blackwell, 2006.

19. Alizadeh AA, Eisen MB, Davis RE, et al. Distinct types of diffuse large B-cell lymphoma identified by gene expression profiling. Nature 2000;403:503-511.

20. Hans CP, Weisenburger DD, Greiner TC, et al. Confirmation of the molecular classification of diffuse large B-cell lymphoma by immunohistochemistry using a tissue microarray. Blood 2004;103:275-282.

21. Kremer M, Spitzer M, Mandl-Weber S, et al. Discordant bone marrow involvement in diffuse large B-cell lymphoma: comparative molecular analysis reveals a heterogeneous group of disorders. Lab Invest 2003;83:107-114.

22. Howell SJ, Grey M, Chang J, et al. The value of bone marrow examination in the staging of Hodgkin's lymphoma: a review of 955 cases seen in a regional cancer centre. Br J Haematol 2002;119:408-411.

23. Jeong SY, Chang YH, Lee JK, Hong YJ, Hong SI, Lee SS. Incidence and histologic patterns of bone marrow involvement of malignant lymphoma based on the World Health Organization classification: a single institution study. Korean J Lab Med 2007;27:383-387.

24. Bartl R, Frisch B, Burkhardt R, Huhn D, Pappenberger R. Assessment of bone marrow histology in Hodgkin's disease: correlation with clinical factors. $\mathrm{Br} \mathrm{J}$ Haematol 1982;51:345-360.

25. Swerdlow SH; International Agency for Research on Cancer; World Health Organization. WHO Classification of Tumours of Haematopoietic and Lymphoid Tissues. Lyon: International Agency for Research on Cancer, 2008.

26. Bene MC, Nebe T, Bettelheim P, et al. Immunophenotyping of acute leukemia and lymphoproliferative disorders: a consensus proposal of the European LeukemiaNet Work Package 10. Leukemia 2011;25:567-574. 
27. Kim JM, Park CJ, Jang SS, et al. Clinico-hematologic findings of leukemic bone marrow involvement in Korean patients with non-hodgkin lymphoma. Lab Med Online 2011;1:81-87.

28. van Dongen JJ, Lhermitte L, Bottcher S, et al. EuroFlow antibody panels for standardized n-dimensional flow cytometric immunophenotyping of normal, reactive and malignant leukocytes. Leukemia 2012;26:1908-1975.

29. The Korean Society of Hematology. Hematology. Seoul: Epublic, 2006.

30. Cheson BD, Pfistner B, Juweid ME, et al. Revised response criteria for malignant lymphoma. J Clin Oncol 2007;25:579-586.

31. Thiele J, Zirbes TK, Kvasnicka HM, Fischer R. Focal lymphoid aggregates (nodules) in bone marrow biopsies: differentiation between benign hyperplasia and malignant lymphoma: a practical guideline. J Clin Pathol 1999;52:294-300.

32. Sehn LH, Scott DW, Chhanabhai M, et al. Impact of concordant and discordant bone marrow involvement on outcome in diffuse large B-cell lymphoma treated with R-CHOP. J Clin Oncol 2011;29:1452-1457.

33. Merli M, Arcaini L, Boveri E, et al. Assessment of bone marrow involvement in non-Hodgkin's lymphomas: comparison between histology and flow cytometry. Eur J Haematol 2010;85:405-415.

34. Campbell J, Seymour JF, Matthews J, Wolf M, Stone J, Juneja S. The prognostic impact of bone marrow involvement in patients with diffuse large cell lymphoma varies according to the degree of infiltration and presence of discordant marrow involvement. Eur J Haematol 2006;76:473-480.

35. Conlan MG, Bast M, Armitage JO, Weisenburger DD. Bone marrow involvement by non-Hodgkin's lymphoma: the clinical significance of morphologic discordance between the lymph node and bone marrow. Nebraska Lymphoma Study Group. J Clin Oncol 1990;8:1163-1172.

36. Morra E, Lazzarino M, Castello A, et al. Bone marrow and blood involvement by non-Hodgkin's lymphoma: a study of clinicopathologic correlations and prognostic significance in relationship to the Working Formulation. Eur J Haematol 1989;42:445-453.

37. Yan Y, Chan WC, Weisenburger DD, et al. Clinical and prognostic significance of bone marrow involvement in patients with diffuse aggressive B-cell lymphoma. J Clin Oncol 1995;13:1336-1342.

38. Ribrag V, Vanel D, Leboulleux S, et al. Prospective study of bone marrow infiltration in aggressive lymphoma by three independent methods: whole-body MRI, PET/CT and bone marrow biopsy. Eur J Radiol 2008;66:325-331.

39. Kwee TC, de Klerk JM, Nievelstein RA. Imaging of bone marrow involvement in lymphoma: state of the art and future directions. ScientificWorldJournal 2011;11:391-402.

40. Hanna SL, Fletcher BD, Fairclough DL, Jenkins JH 3rd, Le AH. Magnetic resonance imaging of disseminated bone marrow disease in patients treated for malignancy. Skeletal Radiol 1991;20:79-84. 